\title{
Mammal use of wildlife crossing structures along a new motorway in an area recently recolonized by wolves
}

\author{
Robert W. Mysłajek $^{1}$ (D) $\cdot$ Emilia Olkowska $^{2} \cdot$ Marta Wronka-Tomulewicz $^{2} \cdot$ Sabina Nowak $^{3}$ \\ Received: 12 February 2020 / Revised: 5 August 2020 / Accepted: 17 August 2020 / Published online: 1 September 2020 \\ (C) The Author(s) 2020
}

\begin{abstract}
Wildlife crossing structures (WCSs) enhance connectivity between habitats of wild animals fragmented by fenced motorways, but factors affecting their use by targeted species remain understudied, particularly in areas recently recolonized by large carnivores. We investigated the use of WCS - 6 overpasses (width 30-45m), 5 large underpasses (width 33-114 m) and 4 small underpasses (width 15-19 m) - located along the A4 motorway in the Lower Silesian Forest (western Poland), a large forest tract recently recolonised by wolves (Canis lupus). Identifying and counting tracks of mammals left on sand-beds as well as individuals recorded by camera traps were used to determine species diversity, number and activity patterns of mammals on WCS, and to reveal seasonal and temporal changes of WCS use over 3 years of study (2010-2013). WCSs were mostly used by wild species $(51.5 \%)$, followed by humans $(34.8 \%)$, livestock and pets (13.7\%). Among wild species, ungulates were the most common (77.4\% of crossings), while lagomorphs and carnivores were recorded less often (15\% and $7.6 \%$ of crossings, respectively). The number of species and crossings of wild mammals, especially wild ungulates and wolves, was substantially higher on overpasses (mean effective number of species (Hill numbers): ${ }^{0} D=7.8,{ }^{1} D=4.1$ and ${ }^{2} D=3.3$ ) than on underpasses $\left({ }^{0} D=6.3,{ }^{1} D=2.9\right.$ and ${ }^{2} D=2.3$ ) and was not affected by distance between WCS and human settlements or WCS width. There was a higher diversity of wild species and more crossings under large extended bridges than on smaller underpasses. The number of species and number of crossings of wild mammals, domestic animals and people increased from 2010 to 2013. There was a significant difference in activity patterns, with almost all wild species being nocturnal, in contrast to people and dogs. There was no relationship between crossing time and rates of wild carnivores and potential prey. We conclude that overpasses, even with steep entrance slopes (25$26.5 \%$ ) or integrated with moderately used gravel roads, maintain movement of wild terrestrial mammals much better than underpasses, and the presence of wolves does not hamper the movement of other wild species. As there are significant temporal changes in use of WCS by mammals, we recommend monitoring WCS in all seasons for at least 3 years as a minimum standard for the post-investment assessment of WCS utilization by animals.
\end{abstract}

Keywords Conservation biology $\cdot$ Animal conservation $\cdot$ Road ecology $\cdot$ Animal movement $\cdot$ Mitigation measures $\cdot$ Passage use

This article is part of the Topical Collection on Road Ecology Guest Editor: Marcello D’Amico

Electronic supplementary material The online version of this article (https://doi.org/10.1007/s10344-020-01412-y) contains supplementary material, which is available to authorized users.

Robert W. Mysłajek

robert.myslajek@biol.uw.edu.pl

1 Department of Ecology, Institute of Functional Biology and Ecology, Faculty of Biology, University of Warsaw, Biological and Chemical Research Centre, Żwirki i Wigury 101, 02-089 Warszawa, Poland

2 FPP Enviro Ltd., Wilcza 50/52, 00-679 Warszawa, Poland

3 Association for Nature "Wolf", Cynkowa 4, 34-324 Twardorzeczka, Poland

\section{Introduction}

Roads have profound effects on wildlife populations (Laurance et al. 2014; Ibisch et al. 2016), due to physical disturbance, traffic mortality and barrier effects (Huck et al. 2010; Colchero et al. 2011; Gibson et al. 2013; Poessel et al. 2014). Various measures have been proposed to mitigate the negative impact of roads on wildlife, including warning signs, reduction of traffic volume, vehicle speed limits, systems of animal detection, deterring of animals through olfactory, audio and visual cues, management of road verges, fencing and placement of wildlife crossing structures (hereinafter WCS) (Forman et al. 2003; D'Angelo and van der Ree 2015; Huijser et al. 2015; Smith et al. 2015). On this issue, however, 
only few of those measures seem to be effective in reducing road mortality and connecting populations on both sides of motorways (Huijser et al. 2008).

WCS aim to maintain road permeability, and their dimensions may vary from narrow tunnels and pipes to large underpasses and overpasses, with their effective use depending on the body mass and behaviour of targeted species (Clevenger and Waltho 2000). For animals with special requirements (i.e. arboreal or flying mammals), rope bridges, glider poles and bat gantries are built (Berthinussen and Altringham 2012; Soanes et al. 2013). Nonetheless, despite the popularity of WCS all over the world, and critical financial investments in their planning and building, we are still far from understanding factors affecting their use by wild animals, especially those for large mammals (van der Ree and van der Grift 2015a, b).

Use of WCS by certain species may be altered by their size, design and location, presence of vegetation and various natural structures (logs, branches and tree stumps) and protective fences along motorways. Also, barriers like rainwater tanks, ditches and other constructions at entrances and the risk of flooding of underpasses, as well as activity of people, play an important role (Ascensão and Mira 2007; Mata et al. 2008; Craveiro et al. 2019; Plante et al. 2019). There is also evidence that use of WCS can be affected by awareness of mammals on such constructions as well as their experiences in passing through (Ascensão et al. 2014). Until now, most studies on the effectiveness of road mitigation measures in Europe have been conducted in the western and southern part of the continent (Spain, Portugal and Croatia) (Blanco et al. 2005; Mata et al. 2005, 2008; Ascensão and Mira 2007; Kusak et al. 2009; Craveiro et al. 2019), while data on utilisation of WCS on motorways in central Europe is still scarce (Mysłajek et al. 2016; Ważna et al. 2020).

The ongoing development of road infrastructure in member states that joined the EU in the twenty-first century coincided with a significant increase of populations of wild ungulates in central Europe (Linnell and Zachos 2010; Borowik et al. 2013), and recent recolonization by wolves (Canis lupus) (Nowak and Mysłajek 2016; Reinhardt et al. 2019). At the same time, an extensive network of Natura 2000 sites was designated through the implementation of the Habitat Directive to protect rare habitats and species, among them wolves (Diserens et al. 2017). In these circumstances, the connectivity of habitats cut by newly constructed motorways has to be maintained to secure the integrity of the Natura 2000 network. Utilisation by wild terrestrial animals of different WCS already built to mitigate the barrier effect of new motorways on the environment is an important factor for planning the next road investments and prompts the need to undertake such research (Fabrizio et al. 2019; Valerio et al. 2019). As free-ranging domestic dogs (C. l. familiaris) and cats (Felis silvestris catus) are abundant in various ecosystems in Central Europe and significantly alter both presence and behaviour of wild animals (Wierzbowska et al. 2016; Krauze-Gryz et al. 2018), they should also be considered in studies on use of WCS by wild-living animals.

Here, we aim to evaluate species composition, number of crossings events and crossing rates by larger terrestrial mammals and mammal activity patterns on WCS in relation to their type and size (overpasses, large and small underpasses), location, presence of humans, dogs and cats as well as operating time. We aimed to test the following hypothesis: (1) species diversity and crossing rate of terrestrial mammals differ depending on type and size of WCS; (2) wild species, domestic animals and people have different patterns of daily activity on the WCS; (3) number of species and crossing rates of animals from different species on WCS increase with time.

\section{Materials and methods}

\section{Study area}

Our study site was a 51.4-km-long section of A4 motorway going through the Lower Silesian Forest (hereinafter LSF), one of the largest forest tracts in the lowland part of Europe (Fig. 1). The forest tract encompasses $c a .1700 \mathrm{~km}^{2}$ and is situated in the south-west part of Poland, near the state border with Germany $\left(\mathrm{N} 51^{\circ} 14^{\prime}-51^{\circ} 37^{\prime}\right.$, E $\left.14^{\circ} 44^{\prime}-15^{\circ} 54^{\prime}\right)$. It is flat terrain, with the highest point reaching only $235 \mathrm{~m}$ a.s.l and is divided by the valleys of a few large rivers and their tributaries, where the lowest point is located at the elevation of 107 $\mathrm{m}$ a.s.l. (Bena 2012). The area is located in the temperate climate zone, but with oceanic character. The mean annual temperature is $8{ }^{\circ} \mathrm{C}$, while annual rainfall varies between 520 and $700 \mathrm{~mm}$. Rain is almost equally spread across the year; there are no significant wet and dry seasons; thus, the risk of flooding is relatively low and has no impact on underpass use. The vegetation season length is 220 days on average (Bena 2012).

Within the northern part of the LSF, there are large military training areas (together totalling $385 \mathrm{~km}^{2}$ ) used by various army forces, including tanks and other heavy weapons. Mean human density in the study area is nearly $50 \%$ lower than the average for the country (71 versus 124 people per 1 $\mathrm{km}^{2}$ ). In the area, the majority of local people live in villages and small towns, but $44 \%$ of them inhabit three larger cities (Bolesławiec, Żary and Żagań, with 26k-40k inhabitants) situated at the edges of the forest tract (Central Statistical Office 2014).

Local forests consist mostly of Scots pine (Pinus sylvestris) (ca. 90\%) with an admixture of birch (Betula sp.), oak (Quercus sp.), Norway spruce (Picea abies) and alder (Alnus sp.). Stands are mainly state-owned and managed by the National Forest Holding "State Forests" on the basis of 10year management plans. Despite the domination of the pine 


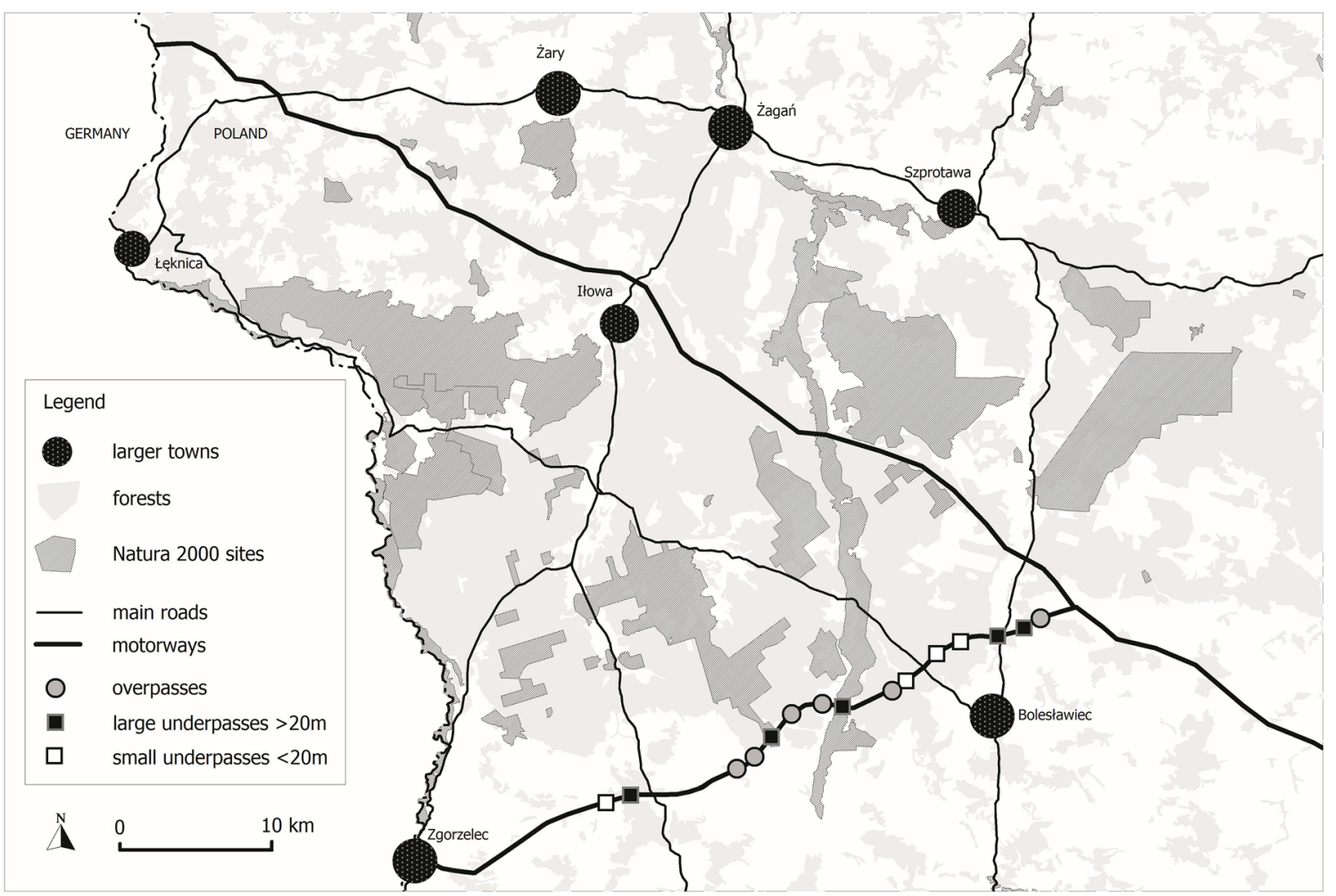

Fig 1 Location of wildlife crossing structures on the A4 motorway (section Zgorzelec-Krzyżowa). See Electronic Supplementary Material Table S1 for detailed description of wildlife crossing structures

monocultures, the area is a habitat for a rich wildlife community. Ungulates are represented mainly by native species: red deer (Cervus elaphus), roe deer (Capreolus capreolus) and wild boar (Sus scrofa), with sporadically recorded individuals of moose (Alces alces) dispersing from other areas and small number of fallow deer (Dama dama), which is an alien species introduced for hunting purpose (Borowik et al. 2013). There are also small and medium-sized carnivores, including native species, such as red fox (Vulpes vulpes), European badger (Meles meles), otter (Lutra lutra), pine marten (Martes martes), stone marten (M. foina), European polecat (M. putorius), stoat (Mustela ermine) and least weasel (M. nivalis), as well as alien species including American mink (Mustela vison), racoon dog (Nyctereutes procyonoides) and racoon (Procyon lotor) (Bena 2012). The LSF is occupied by wolves, which started to recolonize this area in 2007 after years of absence caused by deliberate extermination (Nowak et al. 2011; Nowak and Mysłajek 2016, 2017; Nowak et al. 2017) mainly by individuals originating from the north-east part of Poland (Czarnomska et al. 2013; Szewczyk et al. 2019). During the study period 2010-2013, the wolf population increased in the LSF from six to seven breeding family groups, including 35 adult wolves (Nowak and Mysłajek 2016).

Due to its natural values vast fragments of the LSF are protected. There are numerous although small nature reserves, landscape parks, areas of protected landscape and local nature monuments (Bena 2012). However, the most important are a Special Protection Area designated under the European Union Directive on the Conservation of Wild Birds (SPA, $1721 \mathrm{~km}^{2}$ ) and seven Special Areas of Conservation (SAC) designated under the EU Habitats Directive (together $440 \mathrm{~km}^{2}$ ) (Council Directive 92/43/EEC 1992, Directive 2009/147/EC, Świerkosz et al. 2012; Diserens et al. 2017).

The entire A4 motorway stretches from the west (German border) to the east (Ukrainian border) of Poland and is a part of Trans-European Transport Network (TEN-T) linking EU member states (TENtec Interactive Map Viewer 2019). The western-most section of A4, which is our study area, from Zgorzelec town to Krzyżowa village (51.4 km long), built as a governmental project co-ordinated by the General Directorate for National Roads and Motorways, was put into operation in September 2009 (Fig. 1). The average traffic volume on this section of A4 motorway increased from 11,720 to 18,000 vehicles per day in 2010-2015 (Generalny Pomiar Ruchu 2010, 2015). The motorway cuts through a southern part of the LSF, going through territories of three wolf family groups (Nowak and Mysłajek 2016). It also crosses two Natura 2000 sites (SPA and SAC) (Świerkosz et al. 2012; Diserens et al. 2017), and the western ecological corridor linking Natura 2000 sites in western Poland (Jędrzejewski et al. 2009). This section of the A4 motorway is a four-lane motorway of $27 \mathrm{~m}$ width, fenced along both sides with an exclusion fence made of woven wire $2.4 \mathrm{~m}$ tall buried to a 
depth of 40-60 cm and mesh size decreasing downwards from $25 \times 5 \mathrm{~cm}$ at the top to $5 \times 15 \mathrm{~cm}$ at the ground. Such a solid and continuous fence prevents mortality of bigger terrestrial mammals on the motorway but also creates a barrier in the environment. Based on the Environmental Impact Assessment (EIA) report and public consultations conducted for the A4 motorway in 2006-2007, 16 different wildlife crossing structures for big animals were built on this A4 section in order to facilitate movement of large mammals (including wolves and their potential prey) across the A4 within the LSF as well as to allow exchange of large terrestrial animals between Natura 2000 sites in western Poland along the western ecological corridor (Jędrzejewski et al. 2009). There are also numerous smaller underpasses (culverts) dedicated to amphibians and other small-size animals.

\section{Data collection}

The study lasted 33 months, from October 2010 to June 2013. During this time, we monitored 15 WCS, i.e. six overpasses (two $30 \mathrm{~m}$, two $40 \mathrm{~m}$ and two $45 \mathrm{~m}$ wide, among them four with $12 \%$ and two with $25-26.5 \%$ entrance slopes), and eight underpasses, including seven extended bridges over watercourses (from 15 to $114 \mathrm{~m}$ long) and two box underpasses ( $15 \mathrm{~m}$ and $19 \mathrm{~m}$ wide and $4.5-4.7 \mathrm{~m}$ high) located on the newly built section of the A4 motorway (details in Electronic Supplementary Material-hereafter ESMTable S1). The remaining WCS is located close to Zgorzelec, outside of the LSF, and therefore was not included into this study. The exclusion fence stretching along both sides of the A4 is tightly connected with entrances of all WCS, funnelling bigger animals into passes. To prevent vehicle lights from scaring away animals, all WCSs are equipped with anti-glare screens: overpasses have 2-m-high wooden walls installed on both edges of crossings; underpasses and extended bridges have 1-m-high plastic screens installed over their entrances, on both sides of A4 motorway. The whole A4 and all WCSs have good drainage systems to prevent flooding by heavy rainfall events. Four of the overpasses and two of the underpasses are integrated with forest roads, located close to one edge of the WCS, leaving the rest of the space for crossing animals. Movement of motor vehicles on those roads is by law limited mainly to operations linked with forest management, although cyclists and pedestrians may access them without restrictions.

To collect data on animal activity on WCS, we applied counting of crossing events and identifying tracks of animals left on intentionally prepared track-beds filled with sand, so called sand-beds, as well as complementary camera trap systems (Fig. 2). Alterative solutions (i.e. marble dust and inkbeds) are used for smaller animals on culverts and are not practical methods to monitor large WCS, where both bigger animals and weather conditions (insulation, wind, rain and snowfalls) may easily damage more delicate substrate (Gužvica et al. 2014; Craveiro et al. 2019; Brunen et al. 2020). Sand-beds were solid and stable constructions, to be used for the whole 3 years of the project, to obtain data from different seasons and avoid bias connected with changing seasonal activities of different species. Sand-beds were laid out in the middle of crossing structures with the exception of gravel roads and watercourses with embankments. Locating single sand-beds in the middle of bigger WCS is the most costeffective method of monitoring WCS use and allows passes of animals reaching at least the central point of WCS to be counted. Trenches in the ground, with width of $2.5 \mathrm{~m}$ and depth of $15 \mathrm{~cm}$, were lined with underlay material which is impenetrable for plant roots and then filled with fine sand, rinsed or sieved before, to remove all grains over 2-mm diameter (Gužvica et al. 2014). The sand-beds were checked two times per month for the entire study period with the exception of winter when snow cover persisted. This gave 64 surveys for every WCS throughout the project duration. Every survey consisted of two visits. During the first visit, all tracks were identified into species, and then sand was carefully raked to cover all holes. The second visit took place after 2 days, when again tracks were identified into species and number of crossings of animals of every species (in both direction) were counted, and sand raking was repeated. During winter with snow cover, controls were done 1-3 days after a new snowfall; tracks of animals were identified, and number of crossings across the whole WCS was counted. Tracks of animals were identified by an expert experienced in mammal tracking and based on field guides (Jędrzejewski and Sidorovich 2010). Small mammals leave ambiguous tracks on sand; thus, to avoid bias in analysis, we used only records of animals where size was equal to or greater than European polecat (i.e. $1.5 \mathrm{~kg}$, Aulagnier et al. 2009). The area is inhabited by several species whose tracks are similar; thus, we also grouped tracks of red fox and racoon dog into a single category fox/ raccoon dog, as well as stone marten, pine marten and polecat into a marten/polecat category. The crossing of WCS by an animal or human was considered as successful when animal/ human tracks passed the whole $2.5-\mathrm{m}$ width of a sand-bed, and there were no obvious signs of turn back. Identification of animals and human tracks was conducted for the entire study period, and altogether, we registered 40,281 crossing events of animals and humans on sand-beds (ESM Table S2).

To record the activity of animals and people on the WCS, we installed two types of camera traps with an infrared motion-triggered sensor and IR light-emitting-diode flash array: Bushnell Trophy Cam (Bushnell, USA) and Ecotone HE30 (Ecotone, Poland). Cameras were in heavy-duty metal cases protecting them against weather conditions and possible vandalism or stealing. Devices were installed a maximum of $20 \mathrm{~m}$ apart to cover the entire width of a given WCS with the cameras' detection zone. The motion of warm objects within a 
Fig 2 Techniques applied in the study on the use of wildlife crossing structures on the A4 motorway (section ZgorzelecKrzyżowa). a Sand-bed. b Camera trap

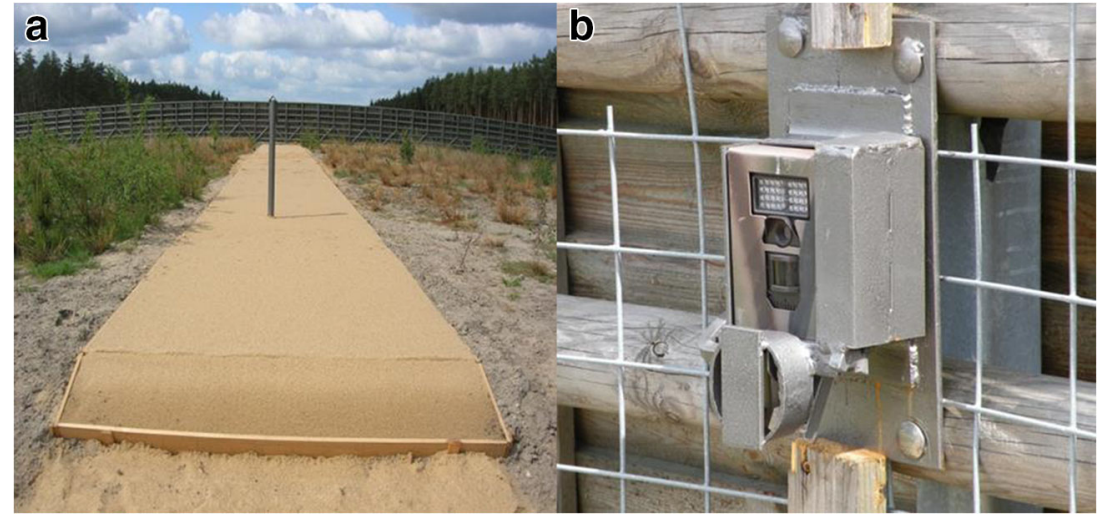

detection zone triggered the cameras to take $30 \mathrm{~s}$ of video footage with a delay of $1 \mathrm{~s}$ between events. Thus, the video footage was recorded only when animals or humans were crossing or walking on the WCS. The very short 1-s delay allowed the same or following animals from the same group to be recorded or to check whether the group or an individual passed successfully across the WSC or turned back. Based on the animals recorded on videos (species, number of animals in a group, differences in size/age, direction of movement, behaviour) as well as information on dates and time of the recordings, we could distinguish between independent events. All situations when animals stayed longer on the WCS (e.g. played on sand, marked or grazed/browsed) were not qualified as crossing events, unless they finally crossed the WCS. On 12 WCS, wider than $20 \mathrm{~m}$, there was more than one camera installed, which allowed crossing events to be checked on video footage from different cameras, when species or number of animals or behaviour were harder to recognise. Cameras were configured to have high sensitivity and to automatically adjust their sensitivity level for night and day. Videos were recorded on secure digital (SD) cards exchanged every second week. Camera traps operated on average for 149 days (range 51-203 days, SD $=49.8$ ) on every monitored WCS. Altogether, we registered 13,364 crossing events of animals and humans with camera traps (ESM Table S3).

From the dataset collected with camera traps, we excluded sampling days when cameras or SD cards malfunctioned or when some of devices were stolen or broken, which then did not allow full cover of the entire width of the crossing structure. We excluded single records (less than $0.1 \%$ of the entire data), both gathered with cameras and on sand-beds, where species identification was ambiguous.

\section{Data analysis}

We thoroughly analysed data collected for every WCS; however, to present differences in utilisation between WCS of various construction and size, we grouped WCS into three categories: overpasses (PZ23, PZ28, PZ34, PZ47, PZ51 and PZ52), large underpasses (more than $20 \mathrm{~m}$ of width, namely MA16, MA25, MA31, MA42, MA46) and small underpasses (less than 20 m of width, namely MA15, MA35, PZ38 and PZ40) (see ESM Table S1 for details).

Using data gathered on sand-beds, we calculated:

1. Dominance $D \%$ using the formula:

$$
D \%=\left(\frac{n_{i}}{N}\right) 100
$$

where $n_{l}$ - the number of crossings by animals of the given species, and $N$ - the number of crossings by animals of all species)

2. The number of crossing events per day $N_{c}$ using the formula:

$$
N_{c}=\frac{n_{i}}{n_{d}}
$$

where $n_{l}$ - the number of crossings by animals of the given species, $n_{d}$ - the number of days with surveys on sand-beds divided by number of days between first and second visit within the same survey (see "Data collection" for details)

3. Constancy $C \%$ using the formula:

$$
C \%=\left(\frac{q_{i}}{Q}\right) 100
$$

where $q_{i}$ - the number of samples with given species, $Q$ - the number of all samples

4. Hill numbers (i.e. effective number of species) - a family of indices, which characterize species diversity of an assemblage incorporating relative abundance and species richness (Hill 1973). For $q \neq 1$, it is defined as 


$$
{ }^{q} D=\left(\sum_{i=1}^{S} p_{i}^{q}\right)^{\frac{1}{1-q}}
$$

The sensitivity of the indices to the relative abundance is determined by the parameter $q$ (Chao et al. 2014; Daly et al. 2018). When $q=0,{ }^{0} D$ is a number of species (species richness $S$ ). When $q=1,{ }^{1} D$ is the exponential of Shannon entropy:

${ }^{1} D=\lim _{n \rightarrow \infty} q D=\exp \left(-\sum_{i=1}^{S} p_{i} \log p_{i}\right)$

When $q=2,{ }^{2} D$ is the Simpson diversity (the inverse of Simpson concentration):

${ }^{2} D=1 / \sum_{i=1}^{S} p_{i}^{2}$

For $q=0$, the measure counts species equally, neglecting their relative abundances. When $q=1$ the measure counts individuals equally, weighting species proportionally to their abundances; therefore, it can be interpreted as the effective number of common species in the assemblage. For $q=2$, the measure places more weight on the dominant species, and thus can be interpreted as the effective number of dominant species in the assemblage. We applied the bootstrap method (100 repeats) to provide standard errors and 95\% confidence intervals. Calculations of diversity indices and similarity measures were done in SpadeR software (Chao et al. 2015). For these analyses, data from sand-beds was used (ESM Table S2). To properly assess the use of WCS by wild mammals, we excluded people and domestic animals from the diversity analysis.

We also calculated dissimilarity in species composition between overpasses, large underpasses (more than $20 \mathrm{~m}$ of width) and small underpasses (less than $20 \mathrm{~m}$ of width) (see ESM Table S1 for details). We pulled together species abundance data from WCS belonging to these three categories to derive similarity indices incorporated into SpadeR (Chao et al. 2015). These indices are also functions of diversity order $q$ (Hill numbers). Therefore, for $q=0$, they are based only on species richness, but for $q>0$, they incorporate species abundances. All similarity measures range from 0 (total dissimilarity) to 1 (total similarity). We also applied the bootstrap method (100 repeats) to provide standard errors and $95 \%$ confidence intervals (see Chao et al. 2015 for further details).

We applied a Mann-Whitney $U$ test to analyse differences of crossing rates of species at different WCS and one-way ANOVA on ranks (Kruskal-Wallis $\mathrm{H}$ test) to analyse seasonal changes in crossing rates by animals from different species on WCS based on data from sand-beds. We defined seasons as follows: spring (March-May), summer (June-August), autumn (October-November), winter (December-February) (Sokal and Rohlf 1994).
We used data obtained from camera traps only to compare the daily activity of animals and people on the WCS. Independent events were counted for time intervals (h) and computed into a species by time-use matrix in which species are arranged in rows, and time intervals are arranged chronologically in columns. The matrix was analysed in the TimeOverlap 1.0. software (Castro-Arellano et al. 2010), which uses the following indices to estimate overlap:

1. Pianka (1973) using the formula:

$$
\alpha_{j, k}=\frac{\sum_{i=1}^{n} p_{i j} p_{i k}}{\sqrt{\sum_{i=1}^{n} p_{i j}^{2} p_{i k}^{2}}}
$$

where $p_{i j}$-the proportional use of time by $i$ species; $p_{i k}$ - the proportional use of time by $k$ species and $n$ - the number of time intervals

2. Czechanowski (Feinsinger et al. 1981) using the formula:

$$
\alpha_{j, k}=1.0-0.5\left(\sum_{i=1}^{n}\left|p_{i j}-p_{i k}\right|\right)
$$

where $p_{i j}$-proportional use of time by $i$ species, $p_{i k}$-proportional use of time by $k$ species and $n$-number of time intervals.

Both calculated time overlap indices equal 0 for species with no overlapping patterns of activity and approaches 1 for species with identical activity patterns. TimeOverlap 1.0. software employs a randomization algorithm (Rosario) that performs random shifts of entire distributions within the time frame of analyses. For each randomization, it calculates the amount of overlap of each group of randomized distributions for each iteration, and significance is determined by comparison of randomized overlap values to the amount of empirical overlap (Castro-Arellano et al. 2010). For all tests, we used 10,000 iterations to generate null distributions, and considered significance at $\alpha=0.05$.

\section{Results}

We recorded 10 wild terrestrial mammal species or groups of species on WCS using sand-beds (ESM Table S2) and camera traps (ESM Table S3). Based on data from sand-beds, WCS were mostly used by wild animals $(51.5 \%)$, followed by humans (34.8\%), livestock and pets (dogs and cats) (13.7\%) (Table S2). Overall, among wildlife, crossings of wild ungulates $(77.4 \%)$ clearly prevailed over the European hare (15\%) and carnivores $(7.6 \%)$, including red fox/raccoon dogs (4.9\%), wolves $(1.1 \%)$, martens/polecat $(1.1 \%)$, European badgers $(0.5 \%)$ and otters $(0.1 \%)$. The number of crossings 
by ungulate species on WCS was dominated by roe deer $(51.7 \%)$, with a smaller share of wild boar $(28.0 \%)$ and red deer $(22.0 \%)$, followed by occasionally recorded fallow deer $(0.7 \%)$.

Overpasses prevailed over underpasses both in the share of wildlife among all recorded crossings of animals and people, and in the quantity of wild animals. On overpasses, an average of $74.5 \%$ of crossings were undertaken by wild species ( $\mathrm{SE}=$ 4.22, range 55.8-86.9), while on underpasses, crossings were merely $28.3 \%$ ( $\mathrm{SE}=3.06$, range 13.0-39.4) (Fig. 3). Also, the number of crossings by wild animals was substantially higher on overpasses, than on underpasses $(\bar{x}=2373, \mathrm{SE}=252.3$, range $1507-3036$ and $\bar{x}=725, \mathrm{SE}=149.5$, range $98-1292$, respectively) (ESM Table S4). The diversity measures for wildlife species was also highest on overpasses (Fig. 4), reaching on average ${ }^{0} D=7.8$ species ( $\mathrm{SE}=0.28$, range 79); ${ }^{1} D=4.1$. ( $\mathrm{SE}=0.24$, range $\left.3.3-5.1\right)$ and ${ }^{2} D=3.3$ ( $\mathrm{SE}=$ 0.23 , range 2.6-4.4) (Fig. 3). Diversity indices for underpasses were lower (average ${ }^{0} D=6.3, \mathrm{SE}=0.27$, range 5-8; average ${ }^{1} D=2.9, \mathrm{SE}=0.14$, range $2.2-3.6$; average ${ }^{2} D=2.3$, $\mathrm{SE}=0.13$, range 1.7-3.0). There were also differences between large ( $>20 \mathrm{~m}$ of width) and small $(<20 \mathrm{~m}$ of width) underpasses. Large underpasses had higher effective number of species than small ones only for $q=0$ (average ${ }^{0} D=6.6$, SE $=0.42$, range $5-8$, and average ${ }^{0} D=6.0, \mathrm{SE}=0$, respectively). For common $(q=1)$ and dominant species $(q=2)$, however, large underpasses had lower diversity measures (average ${ }^{1} D=$ $2.8, \mathrm{SE}=0.16$, range 2.2-3.4 and average ${ }^{2} D=2.2, \mathrm{SE}=0.14$, range 1.7-2.7) than small ones (average ${ }^{1} D=3.1, \mathrm{SE}=0.12$, range 2.6-3.6 and average ${ }^{2} D=2.4, \mathrm{SE}=0.14$, range 1.8-3.0) (Fig. 3). Dissimilarity indices show that overpasses differ from overpasses the most at $q=1$ (common species) and $q=2$ (dominant species) (ESM Table S5).

On overpasses, the wildlife community was clearly dominated by ungulates ( $85 \%)$, while on underpasses, it was less evident $(60.7 \%)$. Roe deer used all types of WCS. There was

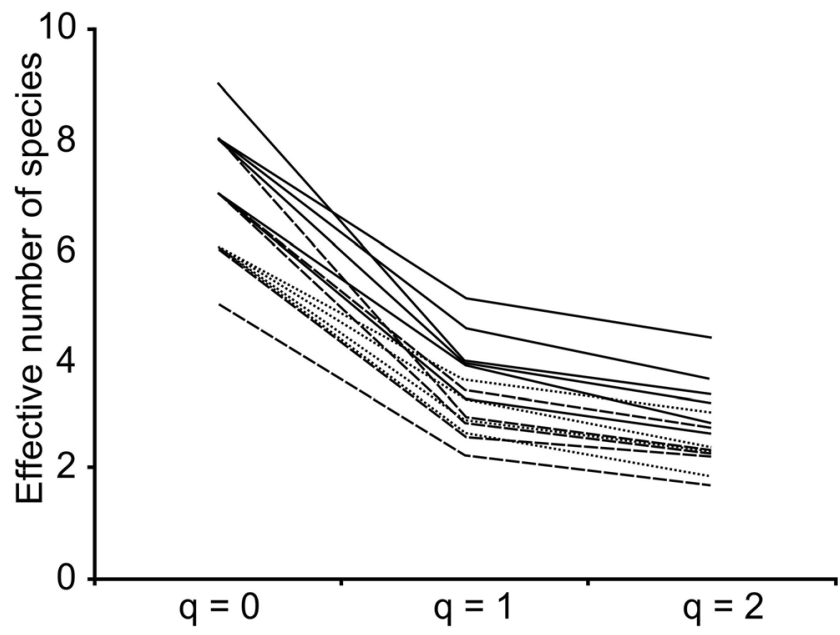

Fig. 4 Effective number of species (Hill numbers) on overpasses (solid line), large underpasses $>20 \mathrm{~m}$ of width (dashed line), and small underpasses $<20 \mathrm{~m}$ of width (dotted line) on the A4 motorway (section Zgorzelec-Krzyżowa), 2010-2013, based on tracks recorded on sandbeds. See Electronic Supplementary Material Table S2 for details

no difference in crossing rates for this species between overpasses and large underpasses; however, it was significantly lower on smaller underpasses. Contrary to this, other wild ungulates were absent (Fallow deer) or very rare (red deer and wild boar) on both types of underpasses. European hare was much often recorded on underpasses $(29.1 \%$ of wildlife crossings), than on overpasses (8.5\%), and its crossing rate was highest on large underpasses. Also, wolves used all types of WCS; their crossing rate, however, was highest on overpasses. Small carnivores constituted the largest constituent of the wildlife community in small underpasses, although, their crossing rate was highest on overpasses. There were, however, differences between species. Small canids (red fox/raccoon dog) and European badger had highest crossing rates on overpasses and martens/polecats on small underpasses, while otters appeared exclusively at large underpasses, along
Fig. 3 Percentage of crossings of wildlife, domestic animals and people on wildlife crossing structures on the A4 motorway (section Zgorzelec-Krzyżowa), 2010-2013, based on tracks recorded on sand-beds. See Electronic Supplementary Material Table S2 for details

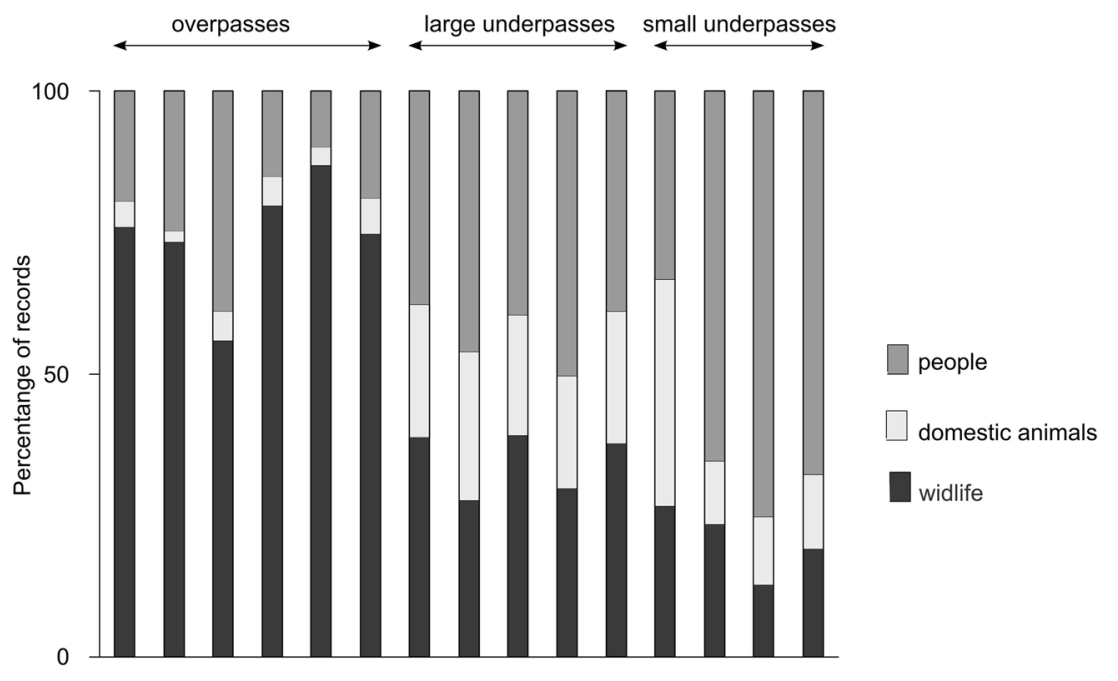


watercourses. Among domestic animals, dogs and cats were the most ubiquitous species; however, they were much more abundant on underpasses. The same pattern was shown by humans (Fig. 5, ESM Table S6).

The mean number of wildlife crossings through WCS (corrected with the WCS width) was positively correlated with distance to human settlements $\left(y=9 \mathrm{E}-06 x+0.0839, R^{2}=\right.$ $0.0107, p=0.03$ ), but this factor explained merely $1 \%$ of the variance. The number of crossings of wildlife on overpasses with steep (25-26.5\%) entrance slopes (mean 6.39 crossings/ day, $\mathrm{SE}=40$, range 0-23) was significantly higher than for overpasses with gentle (12\%) entrance slope (mean 5.48 crossings/day, $\mathrm{SE}=0.35$, range 0-59) (Mann-Whitney $U$ test $U=13861, p=0.01$ ). There were also less crossings by people on WCS with steep slopes (mean 1.29 crossings/day, SE = 0.17 , range $0-14$ ) than with gentle slopes (mean 2.01 crossings/day, $\mathrm{SE}=0.16$, range $0-18$ ) (Mann-Whitney $U$ test $U=$ $13140.5, p=0.001)$. Even the largest underpasses, i.e. extended bridges with functional space (span excluding river bed) reaching $103 \mathrm{~m}$, were less used by wild animals than overpasses having a maximum $45 \mathrm{~m}$ of width (ESM Table S6).

Based on data collected on sand-beds, among wild animals, only wolves had clear seasonal differences in crossing rates on
WCS, with peaks recorded in winter (ESM Table S7). By contrast, red deer and roe deer crossing rates were lower in winter, although this pattern was weaker than for the wolf. Similarly, people and cats' crossing rates were lower on WCS in winter. The crossing rates of animals from other species were more or less equal throughout the year. Moreover, we recorded an increase in numbers of crossings by the majority of wild species, domestic animals and people in subsequent years of the monitoring (Fig. 6, ESM Table S8). The only exception was the red deer whose number of crossings was constant for the 3 years of monitoring and domestic dog recorded most often during the first year of the monitoring.

Data from camera traps showed that there was a significant difference in activity patterns between wild species, humans and pets (Fig. 7). While almost all wild species were nocturnal, people and dogs tended to be diurnal. Among wild species, only red foxes had a higher level of activity during the day, while among domestic animals, cats were more nocturnal. Those differences were clearly confirmed by indices of overlap of daily activity patterns (ESM Table S9). The activity patterns of wolves had a strong overlap with timing of activity of all prey species, both wild ungulates and the European hare. Contrary to
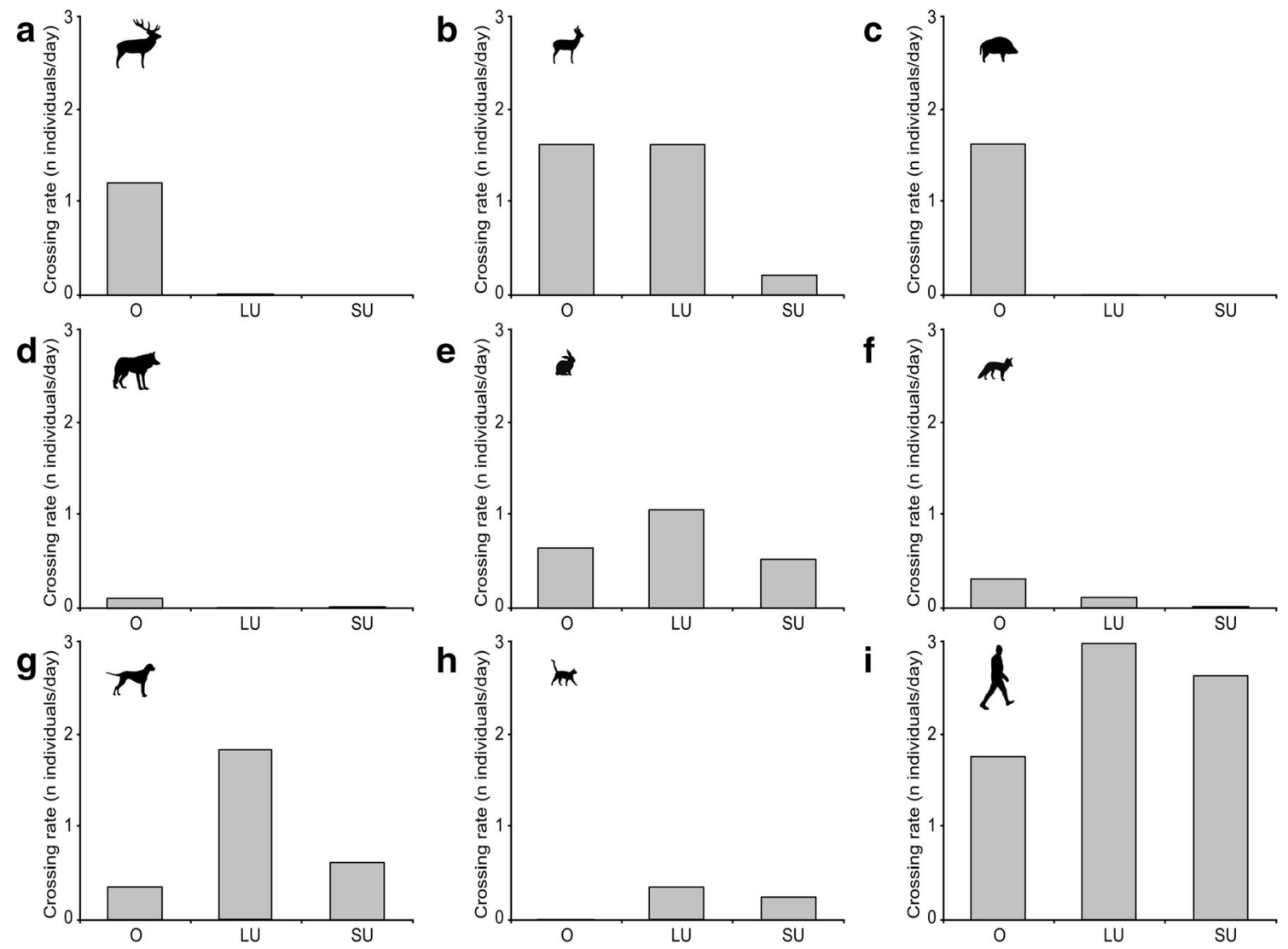

Fig. 5 Crossing rates of selected species of wild and domestic animals, and people on overpasses (O), large underpasses (LU) and small underpasses (SU) on the A4 motorway (section Zgorzelec-Krzyżowa), 2010 2013, based on tracks recorded on sand-beds: (a) red deer; (b) roe deer;

(c) wild boar; (d) grey wolf; (e) European hare; (f) red fox/raccoon dog; (g) domestic dog; (h) domestic cat; (i) people. See Electronic Supplementary Material Table S2 and Table S6 for details 

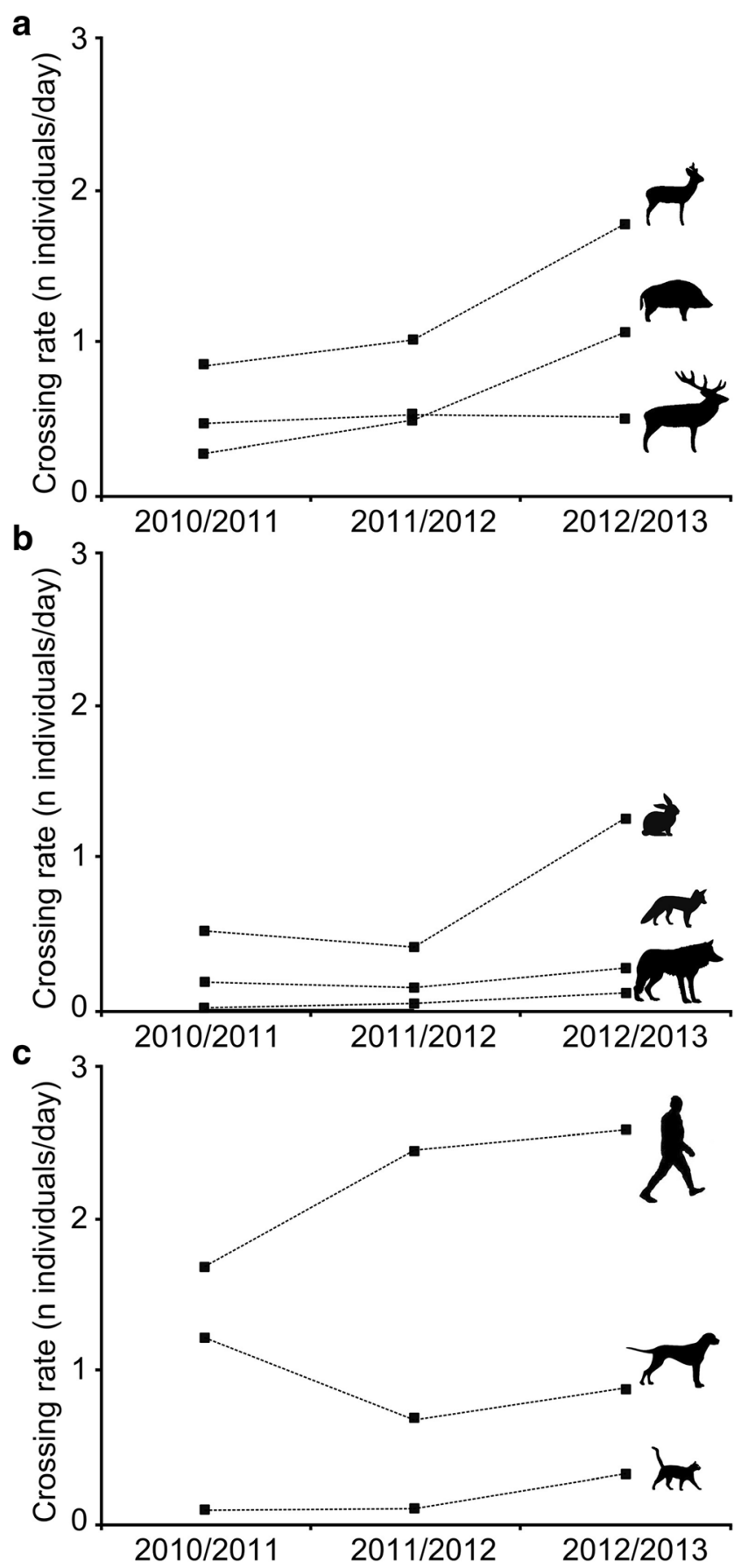

Fig. 6 Changes in crossing rates of selected species of wild and domestic animals, and people on wildlife crossing structures on the A4 motorway (section Zgorzelec-Krzyżowa), from 2010 to 2013. From up to down: (a) roe deer, wild boar, red deer; (b) European hare, red fox/racoon dog, wolf; (c) people, domestic dog, domestic cat. Data based on tracks recorded on sand-beds. See Electronic Supplementary Material Table S8 for details

this, activity patterns of people strongly overlapped with the timing of activity of dogs and cats but differed from the timing of activity of most of wild species. The only wild species with which activity patterns of people overlapped was the red fox (ESM Table S9).

\section{Discussion}

Our study provided further evidence that to sustain movement of a wide range of wild mammals across fenced motorways, overpasses are superior to underpasses. Overpasses located on the A4 motorway have a width of 30-45 m, which is far below the size recommended for such structures in Europe (i.e. $80 \mathrm{~m}$, Smith et al. 2015). Nonetheless, they were used by more species and had higher crossing rates of wild animals than underpasses, among which most have larger functional space for animals. Overpasses proved to be especially suitable for wild ungulates, which corresponds to studies in North America showing that the mule deer (Odocoileus hemionus) and the pronghorn (Antilocapra Americana) have greater passage rates at overpasses than underpasses (Sawyer et al. 2016; Simpson et al. 2016).

Overpasses with steep (25-26.5\%) entrance slopes had higher average number of crossings of wild animals and similar number of species, but lesser human activity, than those with gentle (12\%) entrance slopes. These findings contradict recommendations for overpasses in lowlands to have gentle, i.e. less than 15\% (Iuell et al. 2003; Jędrzejewski et al. 2009; Kurek 2010) entrance slopes. The most important drawback of this solution is that in flat areas, there is a need to extend entrances leading to WCS far into areas adjacent to roads, which is often connected with significant earthworks and the destruction of existing habitats. Therefore, building WCS with steeper entrance slopes might be a better solution from both economic and ecological points of view.

Although overpasses were used by a wide range of species, they were not convenient structures for those with specific habitat requirements, like otters, which usually move along watercourses. Thus, for semiaquatic species, essential features for WCS involve securing the free flow of water and providing enough space for river banks (Serronha et al. 2013). Nonetheless, our studies proved also that among underpasses, larger constructions (> $20 \mathrm{~m}$ of width) are used by larger number of species and have higher crossing rates than smaller ones, and so should be considered during road investments elsewhere.

We found a weak relationship between crossing rates of wild animals and proximity of WCS to human settlements, but we revealed strong differences in daily activity patterns between wildlife, domestic animals and people. We also noticed that human presence on underpasses (especially under extended bridges over rivers) was much more pronounced, not only by the higher crossing rate of people (Fig. 5, ESM Table S6), but also by damage (e.g. presence of fire, drawings on the walls, numerous garbage) or even use of the space under bridge for fishing, other recreation or to store farming accessories (Pierużek-Nowak and Mysłajek 2010). Results of other studies provide contradictory conclusions on responses of wildlife to human presence on WCS. In some areas, 

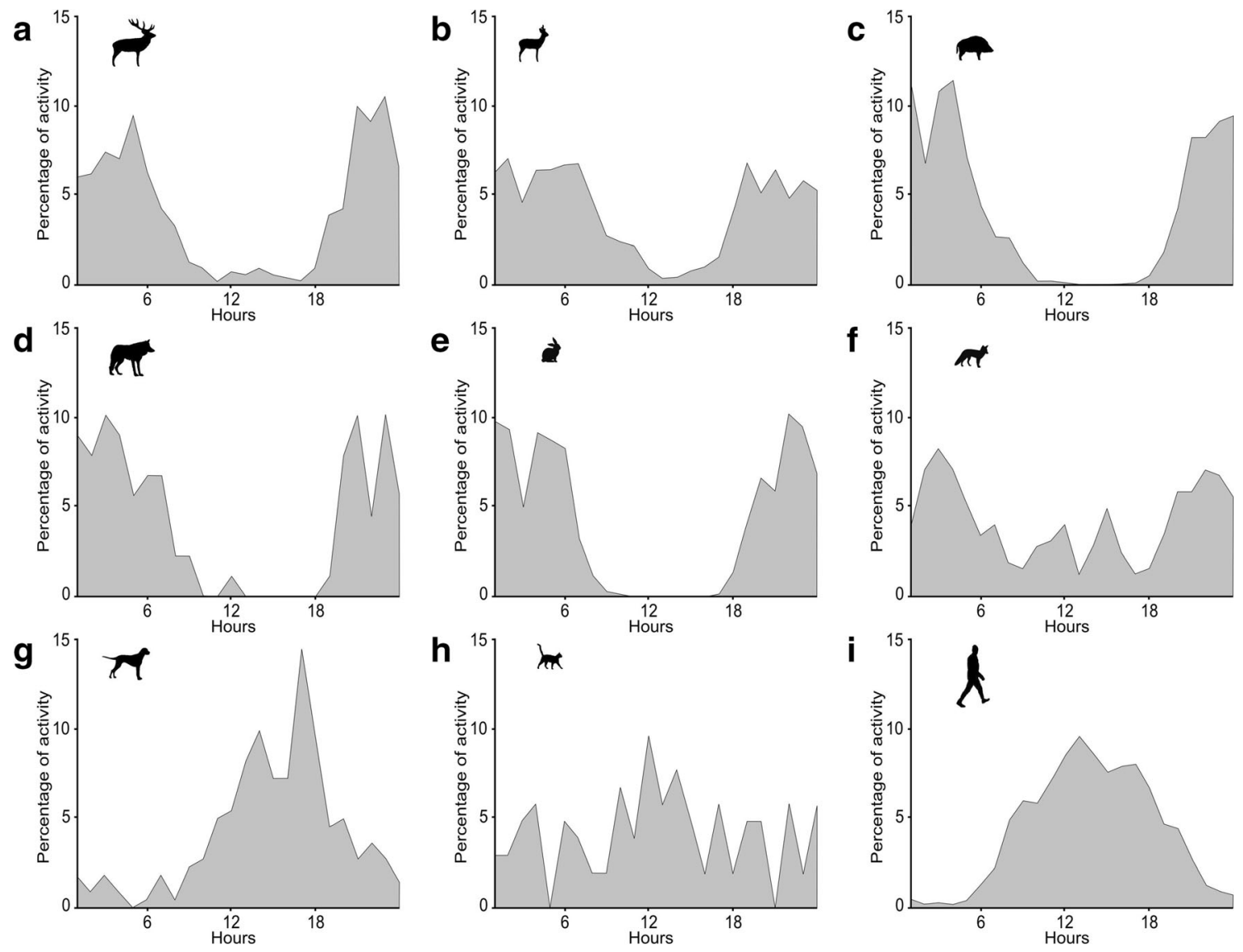

Fig. 7 Patterns of diurnal activity of selected species of wild and domestic animals, and people on wildlife crossing structures on the A4 motorway (section Zgorzelec-Krzyżowa), 2010-2013. (a) Red deer. (b) Roe deer. (c) Wild boar. (d) Wolf. (e) European hare. (f) Red fox/racoon

dog. (g) Domestic dog. (h) Domestic cat. (i) People. Data based on camera traps. See Electronic Supplementary Material Table S3 and Table S9 for details

presence of humans negatively affected the rate of crossings by some species (Ng et al. 2004; Clevenger and Waltho 2000, 2005; Grilo et al. 2008), while in other studies, there was lack of impact or the relationship was positive (Rodriquez et al. 1997; Gloyne and Clevenger 2001; Mata et al. 2005; Seidler et al. 2018). It leads to the conclusion that responses of wild mammals to human presence at WCS are context dependent.

One mechanism that may explain this variety is plasticity in behavioural responses of wild animals to human disturbance across the gradient of urbanization. Studies on birds, mammals and reptiles have shown that animals from populations living in urbanized landscapes are more tolerant to human presence than those from rural or natural areas (Engelhardt and Weladji 2011; Samia et al. 2015; Mikula et al. 2018). Another mechanism may be the adjustment of activity patterns, as shown in our study, where wild mammals avoided encounters with humans by being more nocturnal. Nonetheless, even animals living in close proximity to humans modulate their responses according to the level of risk, e.g. they are not afraid of people behaving in a predictable manner (i.e. staying on roads or tourist routs) but are sensitive to direct attention of humans (Bateman and Fleming 2014). Thus, we support suggestions that multi-use WCS should be sufficiently large and carefully designed to separate wild animals and people (van der Ree and van der Grift 2015a, b).

Although human presence may affect the utilization of WCS by wild species, it is not the only factor, which should be taken under consideration. Overpasses on the A4 motorway are overgrown with dense shrubs, young Scots pine trees and herbaceous plants, which blend very well with the surrounding habitats helping animals to feel safe and find cover. By contrast, the ground under extended bridges is covered only with grass and herbaceous plants, while underpasses are almost devoid of vegetation, thus providing no cover for larger mammals. To encourage use of WCS by wild animals, their functional space should resemble the adjacent habitats. Therefore, enrichment of underpasses with features providing shelter for animals, such as root snags, logs, branches or rocks, is highly recommended (Jędrzejewski et al. 2009; Smith et al. 2015). Another factor which seems to be important for utilization of WCS by wildlife is light and noise pollution (Iglesias et al. 2012; Gaston and Holt 2018). Video-footage with sounds recorded on WCS on the A4 motorway also revealed that bigger mammals negatively reacted to lights, noise and vibrations of WCS constructions caused by vehicles although 
such an effect was noticed only on underpasses (Mysłajek et al. in prep.). Thus, while deciding what construction of WCS should be used, those that efficiently reduce noise levels and vibrations should be taken under consideration.

In our study, we did not record any video footage or evidence on sand-beds that wild carnivores used WCS to ambush prey, which support findings of previous research (Little et al. 2002). All WCS used by wolves or red foxes were regularly and simultaneously used by prey species, such as ungulates and lagomorphs (Panzacchi et al. 2008; Nowak et al. 2011; Panek 2013), and we found no relationship between crossing time and rates of wild carnivores and their potential prey. Moreover, wolves and wild ungulates had a strong overlap in activity patterns. For red foxes, the overlap with either European hares or roe deer was not obvious, but the reason was probably connected with different daily activity pattern of these species. Domestic predators (dogs and cats) in comparison to wild carnivores were much more abundant on WCS (ESM Table S2). Both species are well known as predators of a wide range of wild mammals (Wierzbowska et al. 2016; Krauze-Gryz et al. 2018), and their presence may have an impact on both abundance and activity patterns of potential prey (Loyd et al. 2013; Zapata-Ríos and Branch 2016). Due to the high number of domestic dogs and cats in human-altered European landscapes, in-depth research is needed to clarify their impact on WCS use by wild species.

Numerous studies revealed seasonal differences in species composition and numbers of animals using WCS (Gloyne and Clevenger 2001; Mata et al. 2005; Mysłajek et al. 2016). The abundance and diversity of species is mostly highest in summer and lowest in winter and is mainly connected with species life histories, e.g. in central Europe some mammals, and all amphibians and reptiles hibernate during seasons with low temperatures, while numerous species of birds migrate. However, some species, such as large carnivores, were more often recorded at WCS during winters, e.g. cougars (Puma concolor) in Canada (Gloyne and Clevenger 2001) or wolves in our study area (ESM Table S7). In spring and summer, large carnivores, especially females, often restrict their activity to core areas of their home ranges to provide better care for their offspring and travel for longer distances in winters (Jędrzejewski et al. 2001, 2002). In the LSF, the A4 motorway is located at the edge of the forest, far from breeding places of local wolf family groups. The lower activity at WCS in winter was also noticed for people and domestic cats in our study. Therefore, we suggest that monitoring of WCS in areas with strongly marked seasons should be conducted throughout all seasons. Such a procedure allows proper estimation of species composition of wild mammals using WCS and gives better credibility to the assessment of the impact of people and domestic animals.

We have also provided further evidence for the hypothesis that wild animals require time to adapt to WCS (Clevenger and Waltho 2000; Gagnon et al. 2011; Seidler et al. 2018). In our study, crossing frequency for almost all wild species, with the exception of red deer, grew gradually throughout 3 years of the monitoring. The increase in crossing rate was observed also in the case of people and cats, but not for dogs. The observed pattern was most likely caused by gaining experience and learning, since the camera traps frequently recorded females of red deer, roe deer and wild boar passing along with their offspring, apparently teaching them how to utilize WCS. Therefore, we also recommend monitoring for at least 3 years as a minimum standard for the post-investment assessment of WCS use by wildlife.

Our study revealed that in temperate forests of European lowlands, overpasses, also those with steep (25-25.5\%) entrance slopes or integrated with moderately used gravel roads, maintain movement of wild mammals through fenced motorways much better than underpasses. We believe that those findings can be used in future projects involving the development of road infrastructure in similar environmental conditions.

Acknowledgements Data were obtained within the project conducted by the FPP Enviro Ltd and financed by the General Directorate for National Roads and Motorways. The funding source had no involvement in the study design; collection, analysis and interpretation of data; in the writing of the report and in the decision to submit the article for publication. We would like to thank D. Ślusarczyk for the field assistance and M. Nowak and Dr. K. Kurek for their help in data computing and management. We are grateful to Dr. Chris Young for the linguistic advice.

\section{Compliance with ethical standards}

Permission for conducting studies on wildlife crossing structures was granted by the General Directorate for National Roads and Motorways. According to national law, formal ethical approval is not required for studies based on monitoring of indirect signs of animals, such as tracks, or monitoring of animals with camera traps.

Open Access This article is licensed under a Creative Commons Attribution 4.0 International License, which permits use, sharing, adaptation, distribution and reproduction in any medium or format, as long as you give appropriate credit to the original author(s) and the source, provide a link to the Creative Commons licence, and indicate if changes were made. The images or other third party material in this article are included in the article's Creative Commons licence, unless indicated otherwise in a credit line to the material. If material is not included in the article's Creative Commons licence and your intended use is not permitted by statutory regulation or exceeds the permitted use, you will need to obtain permission directly from the copyright holder. To view a copy of this licence, visit http://creativecommons.org/licenses/by/4.0/.

\section{References}

Ascensão F, Mira A (2007) Factors affecting culvert use by vertebrates along two stretches of road in southern Portugal. Ecol Res 22:57-66

Ascensão F, Grilo C, LaPoint S, Tracey J, Clevenger AP, Santos-Reis M (2014) Inter-individual variability of stone marten behavioral responses to a highway. PLoS One 9(7):e103544 
Aulagnier S, Haffner P, Mitchell-Jones AJ, Moutou F, Zima J (2009) Mammals of Europe, North Africa and the Middle East. A\&C Black Publisher, London

Bateman PW, Fleming PA (2014) Does human pedestrian behaviour influence risk assessment in a successful mammal urban adapter? J Zool 29:93-98

Bena W (2012) Dzieje Puszczy Zgorzelecko-Osiecznickiej. F.H. Agat, Zgorzelec

Berthinussen A, Altringham J (2012) Do bat gantries and underpasses help bats cross roads safely? PLoS One 7(6):e38775

Blanco JC, Cortéz Y, Virgós E (2005) Wolf response to two kinds of barriers in an agricultural habitat in Spain. Can J Zool 83:312-323

Borowik T, Cornulier T, Jędrzejewska B (2013) Environmental factors shaping ungulate abundances in Poland. Acta Theriol 58:403-413

Brunen B, Daguet C, Jaeger JA (2020) What attributes are relevant for drainage culverts to serve as efficient road crossing structures for mammals? J Environ Manag 268:110423

Castro-Arellano I, Lacher TE, Willing MR, Rangel TF (2010) Assessment of assemblage-wide temporal niche segregation using null models. Methods Ecol Evol 1:311-318

Central Statistical Office (2014) Statistical Yearbook of the Regions Poland 2014. Central Statistical Office, Warszawa

Chao A, Chiu CH, Jost L (2014) Unifying species diversity, phylogenetic diversity, functional diversity, and related similarity and differentiation measures through Hill numbers. Annu Rev Ecol Evol Syst 45: 297-324

Chao A, Ma KH, Hsieh TC, Chun-Huo C (2015) User's guide for online program SpadeR (Species-richness prediction and diversity estimation in R). Institute of Statistics, National Tsing Hua University, Hsinchu

Clevenger AP, Waltho N (2000) Factors influencing the effectiveness of wildlife underpasses in Banff National Park, Alberta, Canada. Conserv Biol 14:47-56

Clevenger AP, Waltho N (2005) Performance indices to identify attributes of highway crossing structures facilitating movement of large mammals. Biol Conserv 121:453-464

Colchero F, Conde DA, Manterola C, Chávez C, Rivera A, Ceballos G (2011) Jaguars on the move: modeling movement to mitigate fragmentation from road expansion in the Mayan Forest. Anim Conserv 14:158-166

Council Directive 92/43/EEC of 21 May 1992 on the conservation of natural habitats and of wild fauna and flora. Official Journal of the European Union, L 206, 22/07/1992

Craveiro J, Bernardino J, Mira A, Vaz PG (2019) Impact of culvert flooding on carnivore crossings. J Environ Manag 231:878-885

Czarnomska S, Jędrzejewska B, Borowik T, Niedziałkowska M, Stronen AV, Nowak S, Mysłajek RW, Okarma H, Konopiński M, Pilot M, Śmietana W, Caniglia R, Fabbri E, Randi E, Pertoldi C, Jędrzejewski W (2013) Concordant mitochondrial and microsatellite DNA structuring between Polish lowland and Carpathian Mountain wolves. Conserv Genet 14:573-588

D'Angelo G, van der Ree R (2015) Use of reflectors and auditory deterrents to prevent wildlife-vehicle collisions. In: van der Ree R, Smith DJ, Grilo C (eds) Handbook of road ecology. Wiley, Chichester

Daly AJ, Baetens JM, De Baets B (2018) Ecological diversity: measuring the unmeasurable. Mathematics 6:119

Directive 2009/147/EC of the European Parliament and of the Council of 30 November 2009 on the conservation of wild birds. Official Journal of the European Union, L 20/7, 26/01/2010

Diserens TA, Borowik T, Nowak S, Szewczyk M, Niedźwiecka N, Mysłajek RW (2017) Deficiencies in Natura 2000 for protecting recovering large carnivores: a spotlight on the wolf Canis lupus in Poland. PLoS One 12(9):e0184144

Engelhardt SC, Weladji RB (2011) Effects of levels of human exposure on flight initiation distance and distance to refuge in foraging eastern gray squirrels (Sciurus carolinensis). Can J Zool 89:823-830
Fabrizio M, Di Febbraro M, D'Amico M, Frate L, Roscioni F, Loy A (2019) Habitat suitability vs landscape connectivity determining roadkill risk at a regional scale: a case study on European badger (Meles meles). Eur J Wildl Res 65:7

Feinsinger P, Spears EE, Poole RW (1981) A simple measure of niche breadth. Ecology 62:27-32

Forman RT, Sperling D, Bissonette JA, Clevenger AP, Cutshall CD, Dale VH, Fahrig L, France R, Goldman CR, Heanue K, Jones JA, Swanson FJ, Turrentine T, Winter TC (2003) Road ecology: science and solutions. Island Press, Washington

Gagnon JW, Dodd NL, Ogren KS, Schweinsburg RE (2011) Factors associated with use of wildlife underpasses and importance of long-term monitoring. J Wildl Manag 75:1477-1487

Gaston KJ, Holt LA (2018) Nature, extent and ecological implications of night-time light from road vehicles. J Appl Ecol 55:2296-2307

Generalny Pomiar Ruchu (2010) Generalna Dyrekcja Dróg Krajowych i Autostrad, Warszawa, Poland. https://www.gddkia.gov.pl/pl/987/ gpr-2010. Accessed 20 Jan 2020

Generalny Pomiar Ruchu (2015) Generalna Dyrekcja Dróg Krajowych i Autostrad, Warszawa, Poland. https://www.gddkia.gov.pl/pl/2551/ GPR-2015. Accessed 20 Jan 2020

Gibson L, Lynam AJ, Bradshaw CJA, He F, Bickford DP (2013) Nearcomplite extinction of native small mammal fauna 25 years after forest fragmentation. Science 341:1508-1510

Gloyne CC, Clevenger AP (2001) Cougar Puma concolor use of wildlife crossing structures on the Trans-Canada highway in Banff National Park, Alberta. Wildl Biol 7:117-124

Grilo C, Bissonette JA, Santos-Reis M (2008) Response of carnivores to existing highway culverts and underpasses: implications for road planning and mitigation. Biodivers Conserv 17:1685-1699

Gužvica G, Bošnjak I, Bielen A, Babić D, Radanović-Gužvica B, Šver L (2014) Comparative analysis of three different methods for monitoring the use of green bridges by wildlife. PLoS One 9(8):e106194

Hill MO (1973) Diversity and evenness: a unifying notation and its consequences. Ecology 54:427-432

Huck M, Jędrzejewski W, Borowik T, Miłosz-Cielma M, Schmidt K, Jędrzejewska B, Nowak S, Mysłajek RW (2010) Habitat suitability, corridors and dispersal barriers for large carnivores in Poland. Acta Theriol 55:177-192

Huijser MP, McGowen P, Fuller J, Hardy A, Kociolek A, Clevenger AP, Smith D, Ament R (2008) Wildlife-vehicle collision reduction study. Report to Congress. U.S. Department of Transportation, Federal Highway Administration, USA, Washington

Huijser MP, Mosler-Berger C, Olsson, and M., Strein, M. (2015) Wildlife warning signs and animal detection systems aimed at reducing wildlife-vehicle collisions. In: van der Ree R, Smith DJ, Grilo C (eds) Handbook of road ecology. Wiley, Chichester

Ibisch PL, Hoffmann MT, Kreft S, Pe'er G, Kati V, Biber-Freudenberger L, DellaSala DA, Vale MM, Hobson PR, Selva N (2016) A global map of roadless areas and their conservation status. Science 354 : $1423-1427$

Iglesias C, Mata C, Malo JE (2012) The influence of traffic noise on vertebrate road crossing through underpasses. AMBIO 41:193-201

Iuell B, Bekker GJ, Cuperus R, Dufek J, Fry G, Hicks C, Hlaváč V, Keller VB, Rosell C, Sangwine T, Tørsløv N, Wandall, and le Maire, B. (eds) (2003) Wildlife and traffic: a European handbook for identifying conflicts and designing solutions. COST, vol 341. KNNV Publishers, Delf

Jędrzejewski W, Sidorovich V (2010) The art of tracking animals. Mammal Research Institute Polish Academy of Sciences, Białowieża

Jędrzejewski W, Schmidt K, Theuerkauf J, Jędrzejewska B, Okarma H (2001) Daily movements and terriotory use by radio-collared wolves (Canis lupus) in Białowieża Primeval Forest in Poland. Can J Zool 79:1993-2004 
Jędrzejewski W, Schmidt K, Okarma H, Kowalczyk R (2002) Movement pattern and home range use by the Eurasian lynx in Białowieża Primeval Forest (Poland). Ann Zool Fenici 39:29-41

Jędrzejewski W, Nowak S, Kurek R, Mysłajek RW, Stachura K, Zawadzka B, Pchałek M (2009) Animals and roads. Methods of mitigating the negative impact of roads on wildlife. Mammal Research Institute Polish Academy of Sciences, Białowieża

Krauze-Gryz D, Gryz J, Żmihorski M (2018) Cats kill millions of vertebrates in Polish farmland annually. Glob Ecol Conserv 17:e00516

Kurek RT (2010) Poradnik projektowania przejść dla zwierzat i działań ograniczających śmiertelność fauny przy drogach. Stowarzyszenie Pracownia na rzecz Wszystkich Istot, Bystra

Kusak J, Huber D, Gomerčić T, Schwaderer G, Gužvica G (2009) The permeability of highway in Gorski kotar (Croatia) for large mammals. Eur J Wildl Res 55:7-21

Laurance WF, Clements GR, Sloan S, O'Connell CS, Mueller ND, Goosem M, Venter O, Edwards DP, Phalan B, Balmford A, van der Ree R, Arrea IB (2014) A global strategy for road building. Nature 513:229-232

Linnell JDC, Zachos F (2010) Status and distribution patterns of European ungulates: genetics, population history and conservation. In: Putman R, Apollonio M, Andersen R (eds) Ungulate management in Europe: problems and practices. Cambridge University Press, Cambridge

Little SJ, Harcourt RG, Clevenger AP (2002) Do wildlife passages act as prey-traps? Biol Conserv 107:135-145

Loyd KAT, Hernandez SM, Carroll JP, Abernathy KJ, Marshall GJ (2013) Quantifying free-roaming domestic cat predation using animal-borne video cameras. Biol Conserv 160:183-189

Mata C, Herváz I, Herranz J, Suárez F, Malo JE (2005) Complementary use by vertebrates of crossing structures along a fenced Spanish motorway. Biol Conserv 124:397-405

Mata C, Herváz I, Herranz J, Suárez F, Malo JE (2008) Are motorway wildlife passages worth building? Vertebrate use of road-crossing structures on a Spanish motorway. J Environ Manag 88:407-415

Mikula P, Šaffa G, Nelson E, Tryjanowski P (2018) Risk perception of vervet monkeys Chlorocebus pygerythrus to humans in urban and rural environments. Behav Process 147:21-27

Mysłajek RW, Nowak S, Kurek K, Tołkacz K, Gewartowska O (2016) Utilisation of a wide underpass by mammals on an expressway in the Western Carpathians, S Poland. Folia Zool 65:225-232

Ng SJ, Dole JW, Sauvajot RM, Riley SPD, Valone TJ (2004) Use of highway undercrossing by wildlife in southern California. Biol Conserv 115:499-507

Nowak S, Mysłajek RW (2016) Wolf recovery and population dynamics in Western Poland, 2001-2012. Mammal Res 61:83-98

Nowak S, Mysłajek RW (2017) Response of the wolf (Canis lupus Linnaeus, 1758) population to various management regimes at the edge of its distribution range in Western Poland, 1951-2012. Appl Ecol Environ Res 15(3):187-203

Nowak S, Mysłajek RW, Kłosińska A, Gabryś G (2011) Diet and prey selection of wolves Canis lupus recolonising Western and Central Poland. Mamm Biol 76:709-715

Nowak S, Mysłajek RW, Szewczyk M, Tomczak P, Borowik T, Jędrzejewska B (2017) Sedentary but not dispersing wolves Canis lupus recolonizing western Poland (2001-2016) conform to the predictions of a habitat suitability model. Divers Distrib 23:1353-1364

Panek M (2013) Long-term changes in the feeding pattern of red foxes Vulpes vulpes and their predation on brown hares Lepus europaeus in western Poland. Eur J Wildl Res 59:581-586

Panzacchi M, Linnell JDC, Serrao G, Eie S, Odden M, Andersen R (2008) Evaluation of the importance of roe deer fawns in the spring-summer diet of red foxes in southeastern Norway. Ecol Res 23:889-896

Pianka ER (1973) The structure of lizard communities. Annu Rev Ecol Evol Syst 4:53-74
Pierużek-Nowak S, Mysłajek RW (2010) Raport nr 1. Wstępna ocena stanu technicznego przejść dla zwierząt wzdłuż autostrady A-4 na odcinku Zgorzelec (km 0+000,00) - Krzyżowa (km 51+400,00). FPP Consulting, Warszawa

Plante J, Jaeger JAG, Desrochers A (2019) How do landscape context and fences influence roadkill locations of small and medium-sized mammals? J Environ Manag 235:511-520

Poessel SA, Burdett CL, Boydston EE, Lyren LM, Alonso RS, Fisher RN, Crooks KR (2014) Roads influence movement and home ranges of a fragmentation-sensitive carnivore, the bobcat, in an urban landscape. Biol Conserv 180:224-232

Reinhardt I, Kluth G, Nowak C, Szentiks CA, Krone O, Ansorge H, Mueller T (2019) Military training areas facilitate the recolonization of wolves in Germany. Conserv Lett 12:e12635

Rodriquez A, Crema G, Delibes M (1997) Use of non-wildlife passages across a high speed railway by terrestrial vertebrates. J Appl Ecol 33: $1527-1540$

Samia DSM, Nakagawa S, Nomura F, Rangel TF, Blumstein DT (2015) Increased tolerance to humans among disturbed wildlife. Nat Commun 6:8877

Sawyer H, Rodgers PA, Hart T (2016) Pronghorn and mule deer use of underpasses and overpasses along U.S. Highway 191. Wildl Soc Bull 40:211-216

Seidler RG, Green DS, Beckmann JP (2018) Highways, crossing structures and risk: Behaviors of Greater Yellowstone pronghorn elucidate efficacy of road mitigation. Glob Ecol Conserv 15:e0416

Serronha AM, Mateus ARA, Eaton F, Santos-Reis M, Grilo C (2013) Towards effective culvert design: monitoring seasonal use and behavior by Mediterranean mesocarnivores. Environ Monit Assess 185:6235-6246

Simpson NO, Stewart KM, Schroeder C, Cox M, Huebner K, Wasley T (2016) Overpasses and underpasses: effectiveness of crossing structures for migratory ungulates. J Wildl Manag 80:1370-1378

Smith DJ, van der Ree R, Rosell C (2015) Wildlife crossing structures: an effective strategy to restore or maintain wildlife connectivity across roads. In: van der Ree R, Smith DJ, Grilo C (eds) Handbook of road ecology. John Wiley and Sons, Chichester

Soanes K, Lobo MC, Vesk PA, McCarthy MA, Moore JL, van der Ree R (2013) Movement re-established but not restored: Inferring the effectiveness of road-crossing mitigation for a gliding mammal by monitoring use. Biol Conserv 159:434-441

Sokal RR, Rohlf FJ (1994) Biometry: the principles and practice of statistics in biological resesarch, 3rd edn. W.H. Freeman \& Co, New York

Świerkosz K, Liberacka H, Łysiak M, Zając K (2012) Obszary Natura 2000 na Dolnym Śląsku. Regionalna Dyrekcja Ochrony Środowiska, Wrocław

Szewczyk M, Nowak S, Niedźwiecka N, Hulva P, Špinkytė-Bačkaitienė R, Demjanovičová K, Černá Bolfíková B, Antal V, Fenchuk V, Figura M, Tomczak P, Stachyra P, Stepniak KM, Zwijacz-Kozica T, Mysłajek RW (2019) Dynamic range expansion leads to establishment of a new, genetically distinct wolf population in Central Europe. Sci Rep 9:19003

TENtec Interactive Map Viewer (2019) European Commission. Mobility and Transport. [access 2020-01-20] http://ec.europa.eu/transport/ infrastructure/tentec/tentec-portal/map/maps.html

Valerio F, Carvalho F, Barbosa AM, Mira A, Santos SM (2019) Accounting for connectivity uncertainties in predicting roadkills: a comparative approach between path selection functions and habitat suitability models. Environ Manag 64:329-343

van der Ree R, van der Grift E (2015a) Guidelines for evaluating use of wildlife crossing structures. In: van der Ree R, Smith DJ, Grilo C (eds) Handbook of road ecology. Wiley, Chichester

van der Ree R, van der Grift E (2015b) Recreational co-use of wildlife crossing structures. In: van der Ree R, Smith DJ, Grilo C (eds) Handbook of road ecology. Wiley, Chichester 
Ważna A, Kaźmierczak A, Cichocki J, Bojarski J, Gabryś G (2020) Use of underpasses by animals on a fenced expressway in a suburban area in western Poland. Nat Conserv 39:1-18

Wierzbowska IA, Hędrzak M, Popczyk B, Okarma H, Crooks KR (2016) Predation of wildlife by free-ranging domestic dogs in Polish hunting grounds and potential competition with the grey wolf. Biol Conserv 201:1-9
Zapata-Ríos G, Branch LC (2016) Altered activity patterns and reduced abundance of native mammals in sites with feral dogs in the high Andes. Biol Conserv 193:9-16

Publisher's note Springer Nature remains neutral with regard to jurisdictional claims in published maps and institutional affiliations. 